\title{
Marketing of Political Communication Created by National Mandate Party (PAN) in General Election 2005-2015, North Sumatra, Indonesia
}

\author{
Anang Anas Azhar \\ Social Science Faculty, Islamic University of North Sumatra (UINSU), Medan, Indonesia \\ anang_mb76@yahoo.com
}

\begin{abstract}
PAN establishes itself as an open, independent party, upholding religious morality, humanity and pluralism, aimed at enlightening the nation. PAN is a party born from the womb of the reform movement founded by the figures of reforms across ethnic, racial, religious and class. It is rooted in religious morals, humanity and pluralism. DPW PAN in North Sumatra utilizes various channels of communication, not just to build the image but broader than that, it is to market political communication, strengthen the emotional connection with constituents. The process of marketing is carried out continuously, not only in the run up to election or election events, such as general election of regional but also after the election is done.
\end{abstract}

Keywords: marketing; political communication; general election; pluralism

\section{INTRODUCTION}

In the context of Indonesian politics, the imaging of political parties is often influenced by individual imagery. The dominance of personal image is often identified with the image of the institution. For example, the figure of Susilo Bambang Yudhoyono strengthens the image of the Democratic Party, Prabowo Subianto figure strengthens the image of Gerindra Party, Amin Rais reinforces the image of PAN, as well as the elderly kiyai in the PPP helped strengthen the party's Islamic imagery. In public relations view, the individual image becomes a force in supporting the development of party image. As stated by Saks Agung Wisesa and Macnamara, individual or 
individual as one of the source of imaging, also supports strengthening the strength of image development of the organization. In reality it is understood that not only personal figures can build party imagery. This is because the figure will be very vulnerable in building emotional relationships with constituents in the future. If the figure disappears, it is possible that the party's reputation will undergo a change. Not to mention if in fact the party figure is incapable of being consistent with the struggle of the party and its constituents. Therefore, it has become a consequence for one political party to formulate a special strategy in developing a political strategy in the first place, so that the party's image will still have a place in the hearts of its supporters. To build a political image takes a relatively long time. The public needs a long span of time to see the suitability of their patterns and political channels with a political party. Building imagery also requires consistency of all things that political parties or individuals do like work programs, platforms, reputation. When there is ambiguity or inconsistency, the publicly-recorded image becomes incomplete. Therefore, imaging is a deliberately created impression of an object, person or organization. The image of the organization is very important for every organization. No exception is the political organization which in this case is certainly a political party, because the image of the political party is very influential on the vote in the general election. In other words, a positive image of a political party will be able to attract supporters of mass supporters who can boost the popularity of one party. Seeing the importance of the image for political parties, it is necessary a construction in other words required steps to build or form a positive image of political parties in order to still gain the confidence of the hearts of the community. Empirical facts prove the importance of party imaging, although it takes a long time. Imagery can encourage the election of party votes in the election. As one of the facts that political imagery may influence the direction of the electorate to determine its choice of one party, it can be analyzed from the imagery conducted by the National Mandate Party which furthermore in this dissertation is written with PAN. PAN, as explained by Bahar, is rooted in religious, humanitarian and pluralistic morals. As one of the facts that political imagery can influence the direction of the electorate to determine its choice of one party, it can be examined from the imagery conducted by the National Mandate Party which furthermore in this dissertation 
is written with PAN. PAN is a party born from the womb of the reform movement founded by the figures of reforms across ethnic, racial, religious and class. Therefore, PAN establishes itself as an open, independent party, upholding religious morality, humanity and pluralism, aimed at enlightening the nation. PAN, as explained by Bahar, is rooted in religious morals, humanity and pluralism.

\section{REVIEW OF LITERATURE}

\subsection{Political Competition}

Since the fall of the New Order regime, the end of authoritarian rule in Indonesia has been replaced by the era of democracy, as the product of libertarian ideology. Correspondingly, political liberation arose with the packaging of political democratization which was not actually an indigenous product of Indonesia. Political liberation led to the emergence of many parties. In reality it is seen that the large number of parties participating in the General Election clearly adds to the nuance and pressure of competition. The concept of competition that had not been seen during the New Order era, suddenly became a thing that colored the scene in the nuances of Indonesia politics post reform. This condition immediately encourages the birth of free competition in obtaining or fighting for power. In the increasingly fierce competition, the parties began to apply imaging theory. Political parties are increasingly aggressive and actively seeking and hunting sounds outside the traditional support bases. Following the development of democracy in Indonesia, the key to the process of political struggle is how various political information is contested and constructed in the political arena so as to influence perceptions, attitudes and behavior of voters. At any time, political information continues to grow because of widespread political issues and at the same time also, political issues are increasingly crowded by people from various social class backgrounds. Political information that is often debated concerns two things, namely related to political parties and elites who become candidates in a political contestation. In Indonesia, the political elite is trying to build the image to gain sympathy from the community, so that the intensity of competition in the public space, including in the media 
looks very clear. According to Nyarwi Ahmad, there are three things behind the increasing intensity of imaging political battle, namely the tight competition between contestants, the high demand of society and cultural factors. First, the tight political competition between parties or between candidates fought in political contestation. This example can be considered how the political competition ahead of the arena of Legislative Election, Election of DPD, Presidential Election and Election of Regional Head. The political struggle is not only related to the actual condition of each political party, but also related to the candidates. The limitations of the public in accessing information, also encourage parties and candidates to convey positive political information as much as possible about him, and trying to minimize negative political information that is in him. The party or the candidates is also always trying to pack a variety of political information about him and other positive attributes for him to get to the public mind. Even the tight political competition, also accompanied by new innovations in disseminating and managing information and political messages. Political competitors in general not only convey political information about him, but also provide negative political information also to competitors. This pattern is run with powerful imaging and persuasive techniques by winning teams and political consultants. Second, the tightness of political competition is also influenced by changes in the demands of its constituents. Voters, sometimes referred to as rational voters and some are called emotional voters. In an area, sometimes rational voters constitute the highest number, but sometimes there are few voters of this type. For rational voters, for example, the fighting of political information and political messages is intensified by each political party and candidate. It is intended to shape, influence, change or strengthen the perception, beliefs and behavior of the voters to be in line with the interests of political parties or candidates to win the General Election. Third, cultural factors. Competition and political struggles are also influenced by cultural factors. The cultural factor concerns the culture of elitist political communication as well as the culture of public political communication. There are various types of communication culture in conveying information and political messages. Some tend to be explicit, blatant and otherwise there are also tend to be implicit, delivered with subtle language. The pattern of public respect for the elite also determines the way in which they disseminate information and political messages when it comes 
to the political elite. The moral and cultural regime here becomes the determinant of how the discourse of information and political messages are carried out by the public and the political elite.

\subsection{Persuasion and Suggestion}

Political marketing can also be categorized as one form of political persuasion by parties and politicians to win the hearts of the people. As also confirmed by Arifin, that among the methods most often used by politicians to subdue audiences, besides informative methods, education and coercive is a method of persuasion. Persuasion is one of the most basic forms of communication. Persuasion is defined as a change in attitude due to exposure to information from others. The attitude can be expressed from likes or dislikes. Attitudes are often considered to have three components, namely: First, the affective component, namely the likes or feelings of an object. Second, the cognitive component, ie the belief in an object. Third, the component is related to the behavior, that is the action of the object. Positive imagery will have a positive effect on the attitudes, beliefs and behaviors of the persecuted person. Likewise, negative imagery will negatively affect the attitude of the person being persuaded. Thus, imaging in political communication is highly dependent on the persuasion efforts that are carried out in accordance with the goals desired by the person who is persuading. In this context, imaging management is required or a single arrangement and management of an activity that has a positive impact on imaging. According to Marwoto, the persuasive term in English is called persuasive from the verb to persuade which means to persuade or convince. So persuasion is a discourse that contains persuasion persuasion, or powerless appeal that can generate grit and beliefs of people who are persuaded so that people obey implicit or explicit appeal made by the persuasion. From this it is understood that persuasion is a person's business by giving reasons that convince others to act and act as expected without coercion. Thus, persuasion requires certain efforts to stimulate people to make decisions in accordance with the wishes of the person who persuades. An effort that can be used is to present evidence, though not as firmly as it is done in the argument. And Nimmo explains, there are three kinds of persuasion in political communication: (a) propaganda, (b) political advertising / mass advertising, and (c) rhetoric. Propaganda is directed to individuals as 
members of a community group. Ads are directed to individuals as anonymous units within a wider group. While rhetoric has the nature of one to one communication and usually there is a reciprocal process between the speaker with the audience.

\subsection{Exposure and the Power of Media}

Persuasive imaging politics can be done through mass media, especially through advertising. Media exposure can turn audiences out of power. The study of media exposure that causes audiences to become powerless recognized a number of communication experts, such as Schramm (1971), Berlo (1960), Defleur and Ball Rokeach (1989). In this regard, the election events, the media widely used the party and politicians to perform political imagery. Media is considered to have a strategic role to strengthen the image of politics, because the media is a liaison between communicators with audiences. Communication by using mass media is considered very profitable and can facilitate the dissemination of information related to candidates who are competing, because the mass media cause simultaneity. That is, a message can be accepted by a relatively large number of communicants, wider and heterogeneous. The main strength of mass media use for political communication is the formation of public opinion and political image. The mass media has a major contribution in building understanding of society to its political behavior. One of the determinant factors behind the change in political behavior is the publication of media reporting on political transformation. The strong influence of mass media on political behavior, become a study for experts. Kraus and Davis as quoted by Nurul Syobah explained that the theme of political communication has been done and published since 1959. Kraus and Davis asserted, that the media do the construction of political reality in society. In addition, it also reveals the problems of positioning political communication in cases of practical political activity in the process of transformation and the establishment of political communications of the community. The formation of public opinion is related to the political image, because basically political public opinion is built through political image, while the political image is a consequence of the cognition of political communication. This means that communication does not directly lead to certain opinions or behaviors, but tends to influence the way the imagination organizes its image of the environment and that image affects opinions 
(opinions) or imaginary behaviors. Therefore, there are two possible benefits that can be gained from the use of mass media as a political medium. First, by using mass media, the formation of individual political images can be more precisely targeted toward the desired direction. Second, mass media can also direct the audience (individuals) in maintaining the image they already have. This confirms that the mass media has a strong influence in shaping political perceptions and public image of the public.

\section{RESEARCH METHODOLOGY}

This research is designed as a qualitative research, because the focus of research is on observation and natural atmosphere (naturalistic setting). Research like this, also referred to as naturalistic inquiry, because this research seeks to understand the object being studied as it is, not manipulated but understood through natural analysis. According to Creswell as quoted by Basuki, qualitative research is a process of research to understand human or social problems by creating comprehensive and complex images presented in words, reporting detailed views obtained from the sources of information, and done in the setting ) that is natural. The approach used is a phenomenological approach, because imaging is included in the concentration of political communication studies. Imaging is a form of nonverbal communication by a person or institution, to influence the behavior, thoughts, views, and opinions of others on what is imaged. This study has become more interesting in Indonesia since the 2004 general election. Therefore, phenomenology is chosen as an approach in this research, because the aim is to illustrate the current reality without explaining the relationship between variables. Thus, this study aims to create a systematic, factual and accurate description of the facts of the object under study.

\section{DISCUSSION}

Along with the passage of time, the same as other PAN parties also continue to carry out leadership succession. As soon as the 1999 elections took place, PAN Sumut also began to 
improve itself by conducting a leadership succession. So in the year 2000 Musywil II was held to select the PAN leadership of North Sumatra. In Musywil II, Ibrahim Sakti Batubara was elected chairman of PAN Sumut period 2000-2005 to replace Amri Husni Siregar. In this period, PAN won 8 seats. Next Musywil III PAN held, Ir. H. Kamaluddin Harahap was elected chairman of PAN Sumut 2005-2010 period to replace Ibrahim Sakti Batubara. In this period PAN won seats in North Sumatra parliament as many as 7 seats. Musyawil IV held on August 1, 2010 at the building Selecta Electric Medan. Syah Affandin or who is familiarly called Ondim selected by acclamation to continue the leadership of PAN Sumut period 2010-2015. In this period, PAN obtained 6 seats in North Sumatra DPRD. Musywil V held on June 23, 2015, Zulkifli Husein was elected as Chairman of DPW PAN Sumut period 2015-2020 replaced Syah Affandin (Ondim). In this period, PAN has fulfilled all the stewardship in 33 districts / cities in North Sumatra, then 510 DPC, even the administrators of twigs and sub rayon in the villages. History stands and develops PAN with all its ideals, continuously is the spirit underlying the existence of PAN. The history and ideals of that position are undoubtedly reviewed in order to make sense of the existence of PAN. A thorough understanding of the history and ideals of the founding of the PAN, is an attempt to strengthen its movement as a political party that counts in Indonesia in the future. That is why, in the effort to reach the future, PAN stands on the ideological basis of trust and nationality to be able to respond intelligently and responsibly to the issues of nationality and nobility, and to contribute to the creation of democratic political life in Indonesia. PAN recognizes that as a political party, it cannot avoid the things that are particular to the battleground of political interests in this country. Even the fight is not only between the party's internal counterparts, even the competition with other parties. PAN is a political force in Indonesia which has a basic attitude that the whole process and all the results achieved in the political work is for the sake and to realize the mandate of the people. This is often delivered by Amien Rais who is the founder of PAN, that the birth of PAN is to realize the mandate of the people. While with the ideology of nationality means PAN appreciate and uphold the plurality, heterogeneity or social pluralism, economic and cultural which then compound form a nation state called Indonesia. Thus, the ideology of "amanah" and "nationality" are pillars of PAN's 
buffer as a modernist party. Based on the above descriptions, the authors see that although Muhammadiyah itself is firmly stated that Muhammadiyah is organiza- tionally unaffiliated to any political party. But one thing to remember, that the emotional connection to the establishment of PAN with Muhammadiyah cadres cannot be separated from the historical record. The dominance of PAN's claims of an emotional connection with Muhammadiyah is irrefutable. However, dynamic political developments need to be read in order to see future mass tendencies. Because the level of public confidence, especially cadres Muhammadiyah to the PAN could have decreased, if the romance that once was built, then than forgotten. In that connection, PAN should be more diligent in caring for such emotional and romantic relationships, in addition to the maintenance of a base that is not Muhammadiyah, but their sympathizers, too, are vital. Even the advocacy to the constituents needs to be run consistently, so it is not merely an inspiration. Therefore, the dynamics of politics that continue to grow in Indonesia along with the growing use of mass media, then the mass media should also be utilized as an effort to build a positive image. In addition, other communication channels that are not less important, such as interpersonal communication, group communication and even organizational communication are also very important to do in order to maintain the PAN mass base in North Sumatra. From this emerging development, these communicative efforts have until now been acted by the DPW PAN of North Sumatra in showing their identity as parties that favor the interests of the people, as well as parties that exist in the national political constellation. In the previous chapters it has been explained that imaging has been widely introduced by political observers and politicians often do so in order to boost voting in every election event, both Presidential Election, Head of Region and Legislative Candidate election.One of the observations made, the party that continues to imaging both at the time of the political contestation, or outside it is PAN North Sumatra. From the analysis conducted, the image politics strengthen awareness for political parties related to the importance of the function of various communication channels, in order to bridge the interests of the party with the interests of the constituents. Given the importance of imaging, the DPW PAN Sumut utilize various channels of communication available. As revealed by Agus Salim Ujung. DPW PAN of North Sumatra in principle does not want to be left behind with other parties. 
Especially in terms of broadcasting information to the public, PAN North Sumatra continues and seriously exploit the existence of the growing media today. For PAN of North Sumatra, the utilization of the media, whether print or electronic, is absolutely urgent in raising this party. Particularly in North Sumatra, PAN uses mass media, and we also come down to the regions to come to the constituents, both personally and to our target groups. For example, we have teenage groups built, there are groups of our traders in some areas. In essence, the DPW PAN of North Sumatra even has a bulletin that we distribute and distributed to constituents. It is done on an ongoing basis, whether in times of elections or the owner or beyond. The purpose of doing so, not just for imaging so that PAN people say somebody care or say PAN people populist. But DPW PAN did so, to maintain an emotional bond with the constituents at the grassroots. Based on information obtained from Agus Salim Ujung, it can be understood that DPW PAN Sumut utilize various channels of communication, not just to build the image. But broader than that, is to build political communication, strengthen the emotional connection with constituents, be it within the party as well as outside the party. The process of communication is carried out continuously, not only in the run up to election or election events, such as general election of regional head (Pemilukada), but also after the election is done. It is also understood that in general there are four communication channels commonly used by DPW PAN for imaging as well as political communication, communication channels, new media, billboards, pamphlets, brochures, interpersonal communication and group communication.

\section{CONCLUSION}

When considered the political development in Indonesia, political marketing is not only used by PAN. But in general the other parties do the same. The phenomenon of marketing politics shows the high competition between parties who are frenzied to offer political products. For example, offering ideology, ideas, policies and track records. Communities serve as "markets" to hear, see, choose, even buy their products. According to Firmanzah, there are four main things underlying the importance of using political marketing for political parties. First, 
because there is a shift in the paradigm of voters from ideology to work program. That there is a current development, where people tend to replace the traditional (ideological) ties with more pragmatic matters, namely the work programs offered by parties and politicians. Second, the rise of non-partisan voters, ie non-members or ideologically binding with certain political parties. They are the ones who look more at party programs. Third, the rising mass of floating (floating mass). As the number of non-partisan voters increases, the number of floating masses increases. This floating mass is often very decisive for the winning of a political party in the election, so that they are a group of people contested by parties and politicians in the election. Fourth, the existence of political competition, especially after multiparty system put into effect.

\section{REFERENCES}

Ahmad, Nyarwi. Manajemen Komunikasi Politik dan Marketing Politik: Sejarah, Perspektif dan Perkembangan Riset. Yogyakarta: Pustaka Zaman, 2012.

Alfian, M. Alfan. Menjadi Pemimpin Politik. Jakarta: Gramedia Pustaka Utama, 2009.

Amal, Ichlasul. Teori Mutakhir Partai Politik. Yogyakarta: PT. Tiara Wacana, 1998.

Amir, Mafri. Etika Komunikasi Massa Dalam Pandangan Islam. Jakarta: Logos, 1999.

Ardial. Komunikasi Politik. Jakarta: Indeks, 2010.

Ardianto, Elvinaro dkk. Komunikasi Pengantar; Suatu Pengantar. Bandung: Simbiosa Rekatama Media, 2007.

Arrianie, Lely. Komunikasi Politik; Politisasi dan Pencitraan di Panggung Politik. Bandung: Widya Padjajaran, 2010.

Arifin, Anwar. Komunikasi Politik: Paradigma, Teori, Aplikasi, Strategi Komunikasi Politik

Cravens, David W. Strategic Marketing. USA: Mc-Graw Hill, 2000.

Dhal, Robert, A. Analisis Politik Modern, Terj. Mustafa Kamil Ridwan. Jakarta: PT Bumi Aksara, 1994.

Danial, Akhmad. Iklan Politik TV: Modernisasi Kampanye Politik Pasca Orde Baru. Yogyakarta: Lkis, 2009. 
Darmawan, Ikhsan. Mengenal Ilmu Politik. Jakarta: Kompas Media Nusantara, 2015.

Departemen Pendidikan dan Kebudayaan RI. Kamus Besar Bahasa Indonesia. Jakarta: Balai Pustaka, 2005.

Devito, A. Komunikasi Antar Manusia. Jakarta: Professional Book, 1997.

Dhani, Rendro. Centang Perenang Manajemen Komunikasi Kepresidenan Dari Soekarno Sampai Megawati. Jakarta: Pustaka LP3ES, 2004.

Effendy, Onong Uchjana. Dinamika Komunikasi. Bandung: Remaja Rosdakarya, 2004. . Ilmu Komunikasi Teori dan Praktek. Bandung: PT. Remaja Rosdakarya, 1984.

Efendi, Erwan. Pengaruh Pencitraan Surat Kabar dan Religiusitas Terhadap Penentuan Pilihan

Pemilih Dalam Pemilihan Kepala Daerah Sumatera Utara. Disertasi UIN Sumatera Utara: 2015.

Efriza. Politik Explore: Sebuah Kajian Ilmu Politik. Bandung: Alfabeta, 2012.

Firmanzah. Persaingan, Legitimasi Kekuasaan, dan Marketing Politik. Jakarta: Yayasan Obor Indonesia, 2010.

. Marketing Politik: Antara Pemahaman dan Realitas. Jakarta: Yayasan Obor Indonesia, 2012.

Fukuyama, Francis. Guncangan Besar: Kodrat Manusia dan Tata Sosial Baru, terj. Masri Maris. Jakarta: Gramedia Pustaka Utama, 2005.

Griffin, E. A First Look at Communication Theory. Boston: McGraw-Hil Higher Education, 2000.

Hamad, Ibnu. Konstruksi Realitas Politik dalam Media Massa: Sebuah Studi Critical Discourse Analysis Terhadap Berita-Berita Politik. Jakarta: Granit, 2004.

Haris, Syamsuddin, dkk. Persepsi Masyarakat Terhadap Partai Politik Peserta Pemilu 2004. Jakarta: Pusat Penelitian Politik LIPI, 2003.

Heryanto, Gun Gun. Komunikasi Politik. Jakarta: Universitas Indonesia 2010.

Ilaihi, Wahyu. Komunikasi Dakwah. Bandung: PT. Remaja Rosdakarya, 2010.

Morrisan. Psikologi Komunikasi. Bogor: Indonesia, 2002. 
Nedelmann, Birgitta. Individuals and Parties - Changes in Processes of Political Mobilization.

European Sociological Review: Oxford University Press, 1987), h. 181-202.

Nimmo, Dan. Komunikasi Politik; Khalayak dan Efek. Bandung: Remaja Rosdakarya, 2006. . Komunikasi Politik, Komunikator, Pesan dan Media. Bandung: PT. Remaja Rosdakarya, 2006.

Nursal, Adman. Political Marketing: Strategi Memenangkan Pemilu. Jakarta: PT Gramedia Pustaka Utama, 2004.

Pamungkas, Sigit. Partai Politik: Teori dan Praktik di Indonesia. Yogyakarta: Institut for Democracy and Welfarisme, 2011.

Pito, Toni Andrianus, dkk. Mengenal Teori-Teori Politik. Bandung: Penerbit Nuansa, 2009.

Puspoyo, Widjanarko. Dari Soekarno Hingga Yudhoyono, Pemilu Indonesia 1955 - 2009. Solo: Era Adicitra Intermedia, 2012.

Al-Qardhawy, Yusul. Pedoman Bernegara Dalam Perspektif Islam, Terj. Kathur Suhadi. Jakarta: Pustaka Al Kautsar, 1999.

Rakhmat, Jalaluddin. Islam Aktual. Bandung: Mizan, 1996. . Psikologi Komunikasi. Bandung: Remaja Rosdakarya, 2001. . Metode Penelitian Komunikasi Dilengkapi Contoh Analisis Statistik. Bandung: Remaja Rosdakarya, 1984.

Rauf, Maswardi dan Mappa Nasrun. Indonesia dan Komunikasi Politik. Jakarta: PT Gramedia Utama, 1993.

Rogers, Everett M dan F. Floyid Shoemaker. Communication of Innovations, terj. Abdillah Hanafi. Surabaya: Usaha Nasional, 1981.

Rush, Michael dan Philip Althoff. Pengantar Sosiologi Politik. Jakarta: PT. RajaGrafindo Persada, 2004.

Ruslan, Rosady. Kampanye Public Relation. Jakarta: PT RajaGrafindo, 2007.

Ruslan. Strategi Public Relations, Bauran Public Relations. Yogyakarta: Pustaka Pelajar, 1997.

Sahid, Komarudin. Memahami Sosiologi Politik. Bogor: Ghalia Indonesia, 2015. 
Wahid, Marzuki. "Cirebon, Jawa Barat: Ketika Patronase Mengalahkan Personalisme” dalam Edward Aspinall dan Mada Sukmajati (Ed), Politik Uang di Indonesia: Patronase dan Klientalisme Pada Pemilu Legislatif 2014. Yogyakarta: Penerbit PolGov, 2015.

Wasesa, Silih Agung. Political Branding \& Public Relation. Jakarta: Gramedia Pustaka Utama, 2011 .

Wasesa, Silih Agung dan J. Macnamara. Strategi Public Relations, Membangun Pencitraan Berbiaya Minimal dengan Hasil Maksimal. Jakarta: Gramedia Pustaka Utama, 2010.

Ways, Muliansyah A. Political; Ilmu Politik, Demokrasi, Partai Politik dan Welfare State. Yogyakarta: Buku Litera, 2015.

Zandi, Sakhira. "Teori Komunikasi Massa” dalam Syukur Kholil (ed.). Teori Komunikasi Massa. Bandung: Citapustaka Media, 2011. 